\title{
Parameter recalculation for a rainfall-runoff model with a focus on runoff curve numbers
}

\author{
Tomáš Řehánek ${ }^{1 \otimes}-$ Michal Podhorányi $^{1}-$ Jan Křenek $^{1}$ \\ ${ }^{1}$ IT4Innovations, Vysoká škola báňská - Technická univerzita Ostrava, Ostrava - Poruba, Czechia \\ ${ }^{\bowtie}$ tomas.rehanek@vsb.cz
}

\begin{abstract}
One of the fundamental issues of hydrology is determination of total runoff volume from rainfall. The mutual relationship of these quantities can be experimentally determined by measuring rainfall and runoff. Rainfall-runoff models describe natural relations on the basis of variables determining physio-geographical conditions of a territorial unit as well as hydraulic properties of the respective river network. In the proposed paper, we focused on parameter recalculation of a rainfall-runoff model with focusing on runoff curve numbers $(\mathrm{CN})$. The objective of this study was to update the data $(\mathrm{CN})$ in the old modelling structures within the FLOREON+ (FLOods REcognition on the Net - Study Area) system and replace them with the new ones. The parameters of runoff CN were estimated according to available GIS layers primarily related to the existing soil conditions and land use. In the first phase, the calculation procedure was prepared for the smaller Porubka and Lubina basins, and then it was applied to the whole basin area. The results showed that the new runoff $\mathrm{CN}$ recalculation procedure resulted in reduction of the simulated runoff (peak discharge, volume) in the Odra River sub-basins, which also led to approximation to the real measured runoff in the Ostrava-Svinov profile. The derived method is applicable to other basins as well.
\end{abstract}

\section{Highlights for public administration, management and planning:}

- Runoff volumes resulting from rainfall significantly contribute to risk processes, such as soil erosion and floods.

- The partially automated procedure for rainfall-runoff estimation is preseted, based on data for soil conditions and land cover.

- Derivation is based on the original principles determined by the US Soil Conservation Service and can be applied to any river basin in the area of the Czech Republic.

- In the future, the proposed methodology will be adapted to run within the ArcMap application.

\section{Keywords}

Runoff curve numbers, Rainfall-runoff model, Odra River basin

Received: 04 July 2019

Received in revised form: 04 November 2019

Accepted:

28 November 2019

\section{Introduction}

Runoff volumes resulting from rainfall significantly contribute to risk processes, such as soil erosion and floods (e.g., Apel et al. 2006; Bracken \& Croke 2007; Panagos et al. 2016). One of the crucial hydrological problems is therefore determination of total runoff volume from rainfall. The mutual relationship of these quantities can be experimentally determined by direct measurement of rainfall and runoff. However, for larger territorial units, cer- tain model simplification, which still needs to be verified in available hydrometric profiles, is instrumental. For the purpose of basic simulation of the runoff volume from rainfall, several rainfall-runoff models have been developed. They describe natural relations based on the parameters determining physical geographical features of an area as well as hydraulic properties of a given river network. One of the most frequently used models is the HEC-HMS modelling system, which is a product of the US Army Corps of Engineers (Hydrologic Engineering Center 2016). It is a semi-distributed approach 
based on calculations of runoff volume in sub-basins and their mutual interconnection.

For determination of the runoff volume ratio from rainfall, the Runoff curve numbers (CN) method was selected with its parameters being dependent on soil conditions and hydrologic soil groups as well as on land use. The method was derived by the US Soil Conservation Service (SCS) (National Engineering Handbook 1972), and it has been widely applied so far. In the Czech Republic, it has been applied within the Protection of Agricultural Land from Erosion methodology (Janeček et al. 2012). Moreover, it is also employed by the Czech Hydrometeorological Institute for deriving potential hydrological characteristics (Šercl 2009).

The motivation of the current study was to update old modelling structures within the FLOREON+ (FLOods REcognition on the Net - Study Area) system and replace them with the new ones. Under the modelling structures, we mean RainfallRunoff models with all necessary input data sets. After a certain period of operating the monitoring and forecasting FLOREON+ system (IT4Innovations 2019), the decision was made about input data recalculations. Since the models are based on SCS-CN curve number method, the $\mathrm{CN}$ numbers, as initial data input, were decided to be the object of interest of this study. The second motivation was to propose a scheme for updating $\mathrm{CN}$ numbers automatically. The results uncovered what is the difference between old and newly computed $\mathrm{CN}$ numbers and how significant is the influence on simulations of runoff (study areas - Lubina and Porubka basins). Based on the results from pilot areas, the outputs served as a tool for decision making. If it is worthy to update $\mathrm{CN}$ numbers for whole Moravia-Silesian region (and how often) or keep them in the initial setup. This paper describes the first comparison results as well as it provides the first attempt to propose a process for automated updating. The process was partly implemented so far, but the further investigation still needs to be done. These results bring us one step closer to solving the problem of automatic $\mathrm{CN}$ recalculations. Automatic recalculations may resolve the problem with keeping $\mathrm{CN}$ numbers up to date without manual assistance.

\section{Study area}

In 2006, the FLOREON (FLOods Recognition on the Net) system for integration and operation of monitoring, modelling, prediction, and decision support for disaster management started to be developed in the Moravian-Silesian region at VŠB
- Technical University of Ostrava (IT4Innovations 2019). A crucial part of this system was monitoring of water levels of water courses as well as runoff simulation based on measured and predicted rainfall.

Within this system, four main units, each of which is represented by the river flowing through it, were defined for the Odra River basin in the MoravianSilesian region. They include the Odra River basin up to the confluence with the Opava River as well as the Opava, Ostravice, and Olše river basins. The first of these units was selected to verify the validity of the selected runoff $\mathrm{CN}$ parameters, and thus it has become the subject matter of this study. The study area stretches from Oderské vrchy, where the Odra River has its spring, and the confluence of the Odra and Opava rivers in the southwestern periphery of the City of Ostrava. The main tributaries of Odra in this area include Husí potok and Bílovka and Jičínka, Lubina, and Ondřejnice flowing from Vítkovská vrchovina (highland) and Podbeskydská pahorkatina (upland), respectively. Just past the Odry town, Odra itself turns into a lowland river boasting a number of wellpreserved natural meanders and medieval pond systems. For monitoring of water levels in this area, there are several hydrological stations operated by the Odra River Basin, state enterprise, on the Odra River as well as its tributaries.

In the first stage, input data were surveyed, and the calculation process was verified for the selected pilot basins, i.e. Porubka and Lubina, possessing different physical geographical features (geological structure, soil conditions, river basin gradients). After verification, obtaining of the runoff $\mathrm{CN}$ values was made automatic and applied to the entire study river basin (see Fig. 1).

\section{Input data}

The model of the Odra River basin up to its confluence with the Opava River has already been developed for 51 sub-basins. The input schematization has been performed over the Digital Elevation Model (DEM) with resolution of 25 meters (photogrammetric method). These sub-basins have also been used in this study. Other essential input data include layers representing the current soil conditions and land cover. For verification of the soil properties, the system of Evaluated Soil Ecological Units (ESEU) available via the public service provided by the Ministry of Agriculture of the Czech Republic (Ministerstvo zemědělství 2019). The information about the current land use within the given 


\section{sciendo}

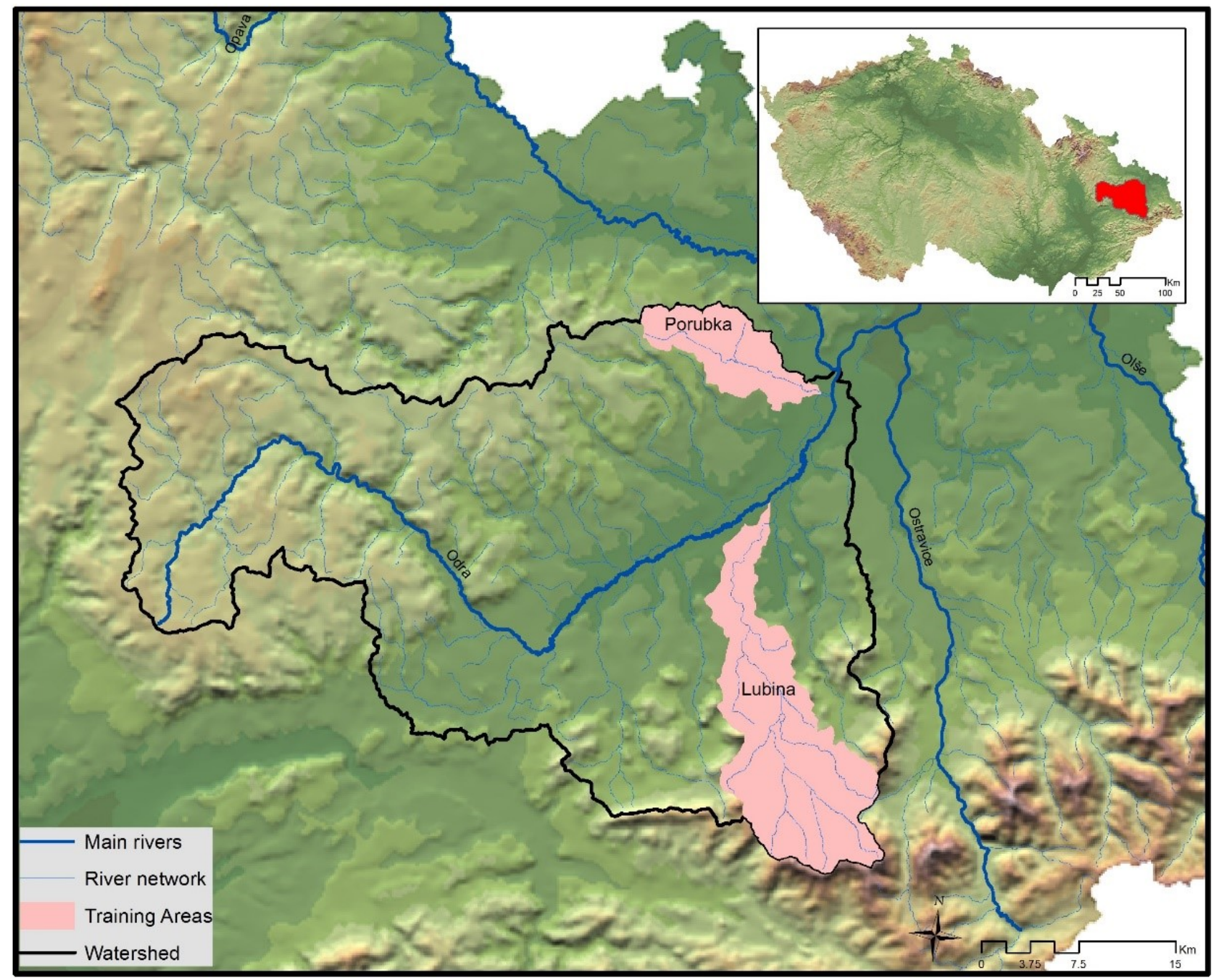

Fig. 1 Odra River basin up to the confluence with the Opava River

area has been acquired from the supporting material published by the European Environment Agency (European Environment Agency 2012), which provides information about the actual land use until the year 2012.

The basis for verifying the values of runoff $\mathrm{CN}$ values was the original data set up for land cover classes and hydrologic soil groups by the US Soil Conservation Service (SCS) (National Engineering Handbook 1972).

The measured total rainfall and discharge during the flood in September 2007 were used from the monitoring network of the Odra River Board Corp., state enterprise (IT4Innovations 2019). This particular emergency situation affected mainly the right tributaries of the Odra River. The most affected basins were those of the Jičínka and Porubka rivers, where 20-year discharge was reached (Řehánek 2008).

\section{Methodology}

Rainfall-runoff model parameters recalculation in this study was focused on verification of total runoff $\mathrm{CN}$ values in all territorial units of the Odra River basin up to the confluence with the Opava River, which are used for runoff simulations in the current FLOREON+ system (Svatoň et al. 2018). For this purpose, updated GIS layers of soil conditions and land cover the overlaying of which served as a base for detailed evaluation of the total runoff from every cell. Updated values of runoff $\mathrm{CN}$, which were taken from the supporting documents refer- 
ring to the mean hydrological soil groups marked by symbol $\mathrm{CN}_{\text {II }}$ and published by the United States Department of Agriculture, were assigned to the resulting detailed units (National Engineering Handbook 2004). A similar approach is usually applied for calculating model hydrological statistics as well. The method for calculating total runoff $\mathrm{CN}$ values is based on the following equation (National Engineering Handbook 1972):

$$
\frac{F}{S}=\frac{Q}{P}
$$

where $\mathrm{F}$ stands for total retention, $\mathrm{S}$ stands for potential retention, $\mathrm{Q}$ for runoff, and $\mathrm{P}$ for total rainfall. By adjusting the formula and incorporating the initial runoff loss, the equation for determining direct runoff is obtained as follows:

$$
Q=\frac{(P-0.2 \cdot S)^{2}}{P+0.8 \cdot S}
$$

Potential retention is then derived from the following equation in inches or converted to SI units (Soulis \& Valiantzas 2012):

$$
S=\frac{1000}{C N}-10
$$

In order to perform semi automation of calculation, the Model Builder software application implemented in ArcGIS 10.x was used. A flowchart containing the select, clip, union, edit, and calculate functions was created.

The resulting total runoff $\mathrm{CN}$ values for the subbasins of the study area were calculated in accordance with the initial method (National Engineering Handbook 2004) using the weighted average method.

\subsection{Soil types}

Soil types and their hydrological properties are one of the fundamental aspects for deriving the total runoff volume using the $\mathrm{CN}$ method. In the study area, several soil types occur. Their formation was affected by different rock composition of the Bohemian Massif and the Western Carpathians with the alluvial plain of the Odra River. In the Beskydy mountains part of the study basin, pseudogleys and anthrosols occur more significantly. However, the soil types such as podzols, rendzinas, pararendzinas, and eutrophic cambisols, which are totally absent in the Jeseníky mountains part of the study area, occur here.

The Main Soil Unit (MSU) is an umbrella term characterizing a group of genetic soil types, soil forming substrates, texture, soil depth, and area relief.
This unit is listed as the second and third number of the Evaluated Soil Ecological Unit (ESEU) code (Novotný \& Vopravil 2013). The evaluation classification system includes altogether 78 MSUs, and their updated values are available via the public service operated by the Ministry of Agriculture of the Czech Republic (Ministerstvo zemědělství 2019). According to the prevailing water infiltration rate, four hydrologic soil groups (HSG) are classified and symbolized by letters A, B, C, and $\mathrm{D}$, where group $\mathrm{A}$ and $\mathrm{D}$ is characterized with the highest and lowest water infiltration rate, respectively. The act of assigning MSU to HSG was performed according to the method (Janeček et al. 2012). In the case of forest soils, however, no ESEUs are set. Identification of the soil properties in these areas can be performed only experimentally by means of probes exploring, for example, the depth of topsoil and its degree of compaction. This study is therefore based on mean forest hydrologic conditions taking into consideration the HSG values in the adjacent agricultural areas with the prevailing HSG group of B.

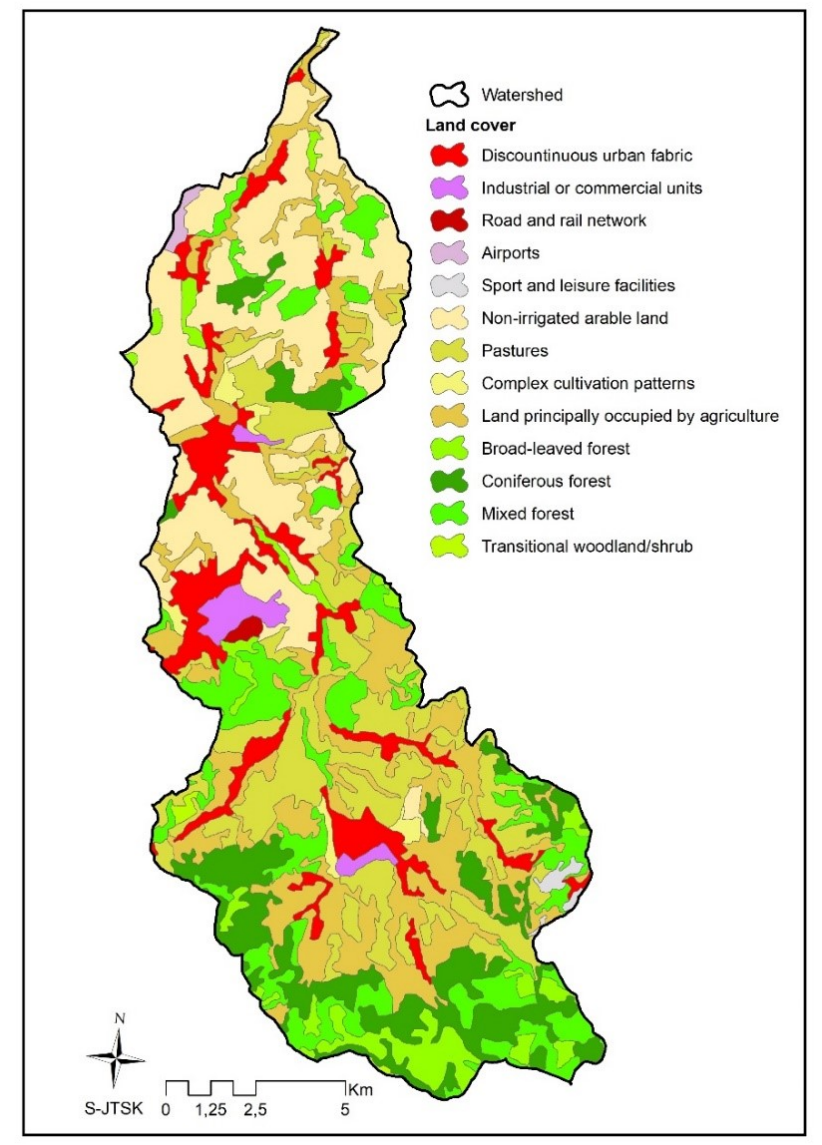

Fig. 2 Cover classes for the pilot Lubina River basin 


\subsection{Land cover}

The second important aspect for deriving runoff $\mathrm{CN}$ values is vegetation and other land cover. Current studies used HEC-HMS as a tool for analyzing the impact of land use and cover change on surface runoff (Younis \& Ammar 2018). The study (Al-Zahrani 2018) focused on land-use changes, and HEC-HMS modelling tool was applied for results evaluations. In this study, we used the land cover classification by the European Environment Agency into 44 classes called CORINE Land Cover (CLC) (European Environment Agency 2000), the 32 of which occur in the study area (see Fig. 2). The available layer of land use at the time of the article's processing refers to the situation in 2012 (European Environment Agency 2012).

Land cover classes, for which the values of runoff CN (National Engineering Handbook 2004) were determined by the US Soil Conservation Service, should be classified according to the current land use defined by the European Environment Agency (European Environment Agency 2000). Some classes were totally identical such as continuous urban fabric, natural grasslands, or forests. In the case of other classes, this classification was performed in a way which best suited the description of a given land use. As a result, an original table containing values of runoff $\mathrm{CN}$ for the land use classes as well as for hydrologic soil types was compiled (see Table 1).

\subsection{Calculation of $\mathrm{CN}$ values}

The prepared maps and tables were used in semiautomated calculation of runoff $\mathrm{CN}$ values for the study area mainly performed using the ArcGIS 10.x software application. Using the Model Builder application, a flowchart containing three defined input layers was created. These layers include area units (river basins) defined by the watershed divides, a layer containing ESEU characteristics, and areas containing data about their land cover. After defining the extent of the area analysed according to the unique classification feature, e.g. hydrological sequence number (HSN), the layers containing applicable ESEU and CLC are attributed to this area, clipped, and displayed. In the next calculation step, the created layers are unified and as a result, the areas of the respective ESEU characteristics as well as with the corresponding CLC land cover class are overlaid. In the attributed table of such generated layer, any unnecessary entries are then removed, and the total surface area of individual unified areas is calculated. The re- sulting GIS layer and table contain all components needed for determining the desired values of runoff curve numbers (see Fig. 3).

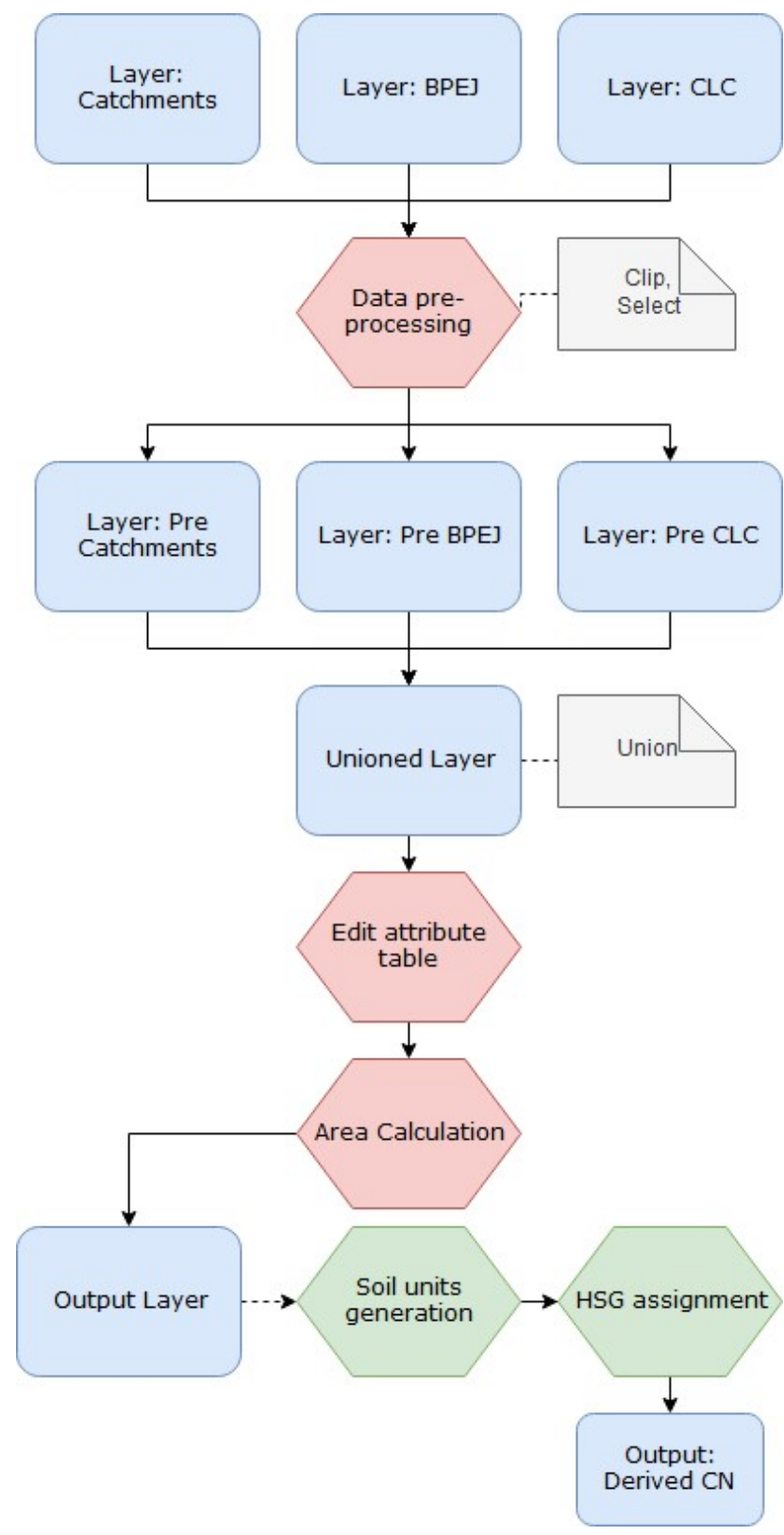

Fig. 3 Flowchart describing the runoff $\mathrm{CN}$ calculation process

The final calculation takes place in the spreadsheet processor, where MSU are automatically generated from the ESEU code, being then attributed the corresponding HSG as well as CLC with defined CN values. The final step is to calculate weighted mean of $\mathrm{CN}$ values and the size of areas for individual unified entries within a particular sub-basin. 
Table 1 CN values for cover classes and hydrologic soil groups

\begin{tabular}{|c|c|c|c|c|c|}
\hline \multirow[t]{2}{*}{ Class } & \multirow[t]{2}{*}{ Land Cover classes } & \multicolumn{4}{|c|}{$\begin{array}{l}\text { CN for hydrologic } \\
\text { soil group }\end{array}$} \\
\hline & & $\mathrm{A}$ & $\mathrm{B}$ & $\mathrm{C}$ & $\mathrm{D}$ \\
\hline 111 & Continuous urban fabric & 89 & 92 & 94 & 95 \\
\hline 112 & $\begin{array}{l}\text { Discountinuous } \\
\text { urban fabric }\end{array}$ & 77 & 85 & 90 & 92 \\
\hline 121 & $\begin{array}{l}\text { Industrial or } \\
\text { commercial units }\end{array}$ & 81 & 88 & 91 & 93 \\
\hline 122 & $\begin{array}{l}\text { Road and rail networks } \\
\text { and associated land }\end{array}$ & 83 & 89 & 92 & 93 \\
\hline 124 & Airports & 83 & 89 & 92 & 93 \\
\hline 131 & Mineral extraction sites & 81 & 88 & 91 & 93 \\
\hline 132 & Dump sites & 81 & 88 & 91 & 93 \\
\hline 133 & Construction sites & 77 & 86 & 91 & 94 \\
\hline 141 & Green urban areas & 49 & 69 & 79 & 84 \\
\hline 142 & $\begin{array}{l}\text { Sport and leisure } \\
\text { facilities }\end{array}$ & 49 & 69 & 79 & 84 \\
\hline 211 & $\begin{array}{l}\text { Non-irrigated } \\
\text { arable land }\end{array}$ & 60 & 72 & 80 & 84 \\
\hline 221 & Vineyards & 43 & 65 & 76 & 82 \\
\hline 222 & $\begin{array}{l}\text { Fruit trees and } \\
\text { berry plantations }\end{array}$ & 43 & 65 & 76 & 82 \\
\hline 231 & Pastures & 30 & 58 & 71 & 78 \\
\hline 241 & $\begin{array}{l}\text { Annual crops associated } \\
\text { with permanent crops }\end{array}$ & 58 & 72 & 81 & 85 \\
\hline 242 & $\begin{array}{l}\text { Complex cultivation } \\
\text { patterns }\end{array}$ & 59 & 74 & 82 & 86 \\
\hline 243 & $\begin{array}{l}\text { Land principally } \\
\text { occupied by agriculture }\end{array}$ & 59 & 74 & 82 & 86 \\
\hline 244 & Agro-forestry areas & 43 & 65 & 76 & 82 \\
\hline 311 & Broad-leaved forest & 36 & 60 & 73 & 79 \\
\hline 312 & Coniferous forest & 36 & 60 & 73 & 79 \\
\hline 313 & Mixed forest & 36 & 60 & 73 & 79 \\
\hline 321 & Natural grassland & 39 & 61 & 74 & 80 \\
\hline 322 & Moors and heathland & 77 & 86 & 91 & 94 \\
\hline 324 & $\begin{array}{l}\text { Transitional } \\
\text { woodland/shrub }\end{array}$ & 35 & 56 & 70 & 77 \\
\hline 331 & $\begin{array}{l}\text { Beaches, dunes } \\
\text { and sand plains }\end{array}$ & 55 & 72 & 81 & 86 \\
\hline 332 & Bare rock & 77 & 86 & 91 & 94 \\
\hline 333 & $\begin{array}{l}\text { Sparsely } \\
\text { vegetated areas }\end{array}$ & 74 & 83 & 88 & 90 \\
\hline 334 & Burnt areas & 77 & 86 & 91 & 94 \\
\hline 411 & Inland marshes & 98 & 98 & 98 & 98 \\
\hline 412 & Peatbogs & 98 & 98 & 98 & 98 \\
\hline 511 & Water courses & 100 & 100 & 100 & 100 \\
\hline 512 & Water bodies & 100 & 100 & 100 & 100 \\
\hline
\end{tabular}

For the Odra River basin up to the confluence with the Opava River, the calculations comprised of thousands of unified entries, and as such they provide an immensely detailed view of the up-to-date curve numbers of this area unit. The newly derived values correspond with the mean hydrological conditions of soils denoted by symbol $\mathrm{CN}_{\mathrm{II}}$.

\section{Results}

The new parameters of the runoff $\mathrm{CN}$ have been incorporated into the original project for the Odra River basin up to its confluence with the Opava River in the HEC-HMS 3.5 Rainfall-Runoff model ${ }^{1}$. The comparative calculations were then feasible for totally identical territorial extent as well as a defined rainfall episode and thus study the role of the newly derived values of runoff $\mathrm{CN}$ played in runoff simulation carried out for the sub-basins within the study area. The pilot calculations performed for the Porubka and Lubina River basins suggested that the $\mathrm{CN}$ values used in the year 2007 overestimated the water runoff as the newly derived curve numbers provided lower values.

By comparing the original and new values of the runoff $\mathrm{CN}$ for the sub-basins within the study area, it was found that in all cases their reduction was achieved. The lowest difference was achieved in the small Odra River sub-basin located past the Porubka River mouth (5\%), and the biggest difference, on the other hand, was achieved in the Odra River sub-basin located between Libavský and Plazský potok (23\%). It can be generally monitored that certain differences were achieved in the upper part of the study area, which is less affected by human activities and is partially located in the Libavá Military Training Area. Smaller differences were then found in areas more affected by agricultural and industrial activities as well as urban areas (see Table 2). More accurate method of runoff $\mathrm{CN}$ values calculation has, of course, affected the simulated flood waves on watercourses within the study area. In comparison with the original derivation of the hydrological situation in September 2007, this time reduction in peak discharge as well as volume of flood waves has been achieved along with shape approximation of the derived runoff to the actually observated ones. The simulated flood waves in the upper, unaffected part of the study basin area have better matched the observed flow rates. In the profile of the Odra hydrological station on the Odra River, the maximum peak discharge of $87 \mathrm{~m}^{3} . \mathrm{s}^{-1}$ was achieved after adjustment of $\mathrm{CN}$ values, which has thus become very closely aligned with the actual measured value of $79 \mathrm{~m}^{3} \cdot \mathrm{s}^{-1}$. Moreover, shape approximation in the area of flood wave rise was achieved (see Fig. 4). Less favourable comparison so far has been generated for the lower part of the Odra River, which indicates the need for adjustment of other parameters affecting the formation of surface runoff in the part of the study basin with intensive anthropogenic use. 
Table 2 Comparison of original and newly derived runoff curve numbers (CN)

\begin{tabular}{|c|c|c|c|c|c|}
\hline ID & Stream & Watershed & $\begin{array}{c}\text { CN } \\
\text { old } \\
{[-]}\end{array}$ & $\begin{array}{c}\text { CN } \\
\text { new } \\
{[-]}\end{array}$ & $\begin{array}{c}\text { Diff. } \\
\text { [\%] }\end{array}$ \\
\hline 1 & Odra & R300W300 & 73.90 & 59.62 & -19.3 \\
\hline 2 & Libavský potok & R150W150 & 75.90 & 62.41 & -17.8 \\
\hline 3 & Odra & R290W290 & 75.50 & 57.92 & -23.3 \\
\hline 4 & Plazský p. & R340W340 & 74.30 & 60.49 & -18.6 \\
\hline 5 & Odra & R160W160 & 74.40 & 59.05 & -20.6 \\
\hline 6 & Lazský p. & R140W140 & 74.50 & 59.68 & -19.9 \\
\hline 7 & Odra & R80W80 & 77.70 & 61.91 & -20.3 \\
\hline 8 & Budišovka & R30W30 & 79.80 & 65.19 & -18.3 \\
\hline 9 & Odra & R120W120 & 75.50 & 65.73 & -12.9 \\
\hline 10 & Něčínský p. & R170W170 & 79.20 & 66.95 & -15.5 \\
\hline 11 & Odra & R190W190 & 78.50 & 64.17 & -18.3 \\
\hline 12 & Čermná & R70W70 & 80.00 & 68.04 & -15.0 \\
\hline 13 & Odra & R260W260 & 79.50 & 67.32 & -15.3 \\
\hline 14 & Suchá & R320W320 & 78.90 & 68.93 & -12.6 \\
\hline 15 & Odra & R330W330 & 80.70 & 71.66 & -11.2 \\
\hline 16 & Luha & R450W450 & 80.70 & 72.97 & -9.6 \\
\hline 17 & Odra & R430W430 & 81.80 & 72.58 & -11.3 \\
\hline 18 & Jičínka & R510W510 & 75.40 & 68.04 & -9.8 \\
\hline 19 & Zrzávka & R460W460 & 77.70 & 69.11 & -11.1 \\
\hline 20 & Jičínka & R440W440 & 83.20 & 76.70 & -7.8 \\
\hline 21 & Odra & R420W420 & 83.10 & 74.45 & -10.4 \\
\hline 22 & Husí p. & R280W280 & 81.20 & 68.71 & -15.4 \\
\hline 23 & Gručovka & R110W110 & 80.20 & 69.01 & -13.9 \\
\hline 24 & Husí p. & R390W390 & 82.50 & 74.29 & -10.0 \\
\hline 25 & Děrenský p. & R350W350 & 81.20 & 71.30 & -12.2 \\
\hline 26 & Husí potok & R380W380 & 83.80 & 76.71 & -8.5 \\
\hline 27 & Odra & R400W400 & 83.60 & 75.39 & -9.8 \\
\hline 28 & Bartošovický p. & R410W410 & 82.30 & 74.87 & -9.0 \\
\hline 29 & Odra & R360W360 & 84.60 & 77.77 & -8.1 \\
\hline 30 & Sedlnice & R370W370 & 82.80 & 74.43 & -10.1 \\
\hline 31 & Odra & R270W270 & 84.80 & 78.88 & -7.0 \\
\hline 32 & Bílovka & R130W130 & 76.70 & 68.88 & -10.2 \\
\hline 33 & Jamník & R100W100 & 80.90 & 71.44 & -11.7 \\
\hline 34 & Bílovka & R180W180 & 84.00 & 75.05 & -10.7 \\
\hline 35 & Sezina & R20W20 & 75.80 & 69.14 & -8.8 \\
\hline 36 & Bílovka & R230W230 & 83.40 & 75.94 & -8.9 \\
\hline 37 & Odra & R200W200 & 85.10 & 77.89 & -8.5 \\
\hline 38 & Lubina & R490W490 & 72.20 & 66.84 & -7.4 \\
\hline 39 & Bystrý p. & R500W500 & 69.50 & 65.56 & -5.7 \\
\hline 40 & Lubina & R470W470 & 78.40 & 68.26 & -12.9 \\
\hline 41 & Tichávka & R480W480 & 78.30 & 70.58 & -9.9 \\
\hline 42 & Lubina & R240W240 & 83.30 & 76.31 & -8.4 \\
\hline 43 & Trnávka & R250W250 & 83.30 & 73.47 & -11.8 \\
\hline 44 & Lubina & R220W220 & 84.40 & 74.46 & -11.8 \\
\hline 45 & Odra & R210W210 & 83.70 & 75.75 & -9.5 \\
\hline 46 & Ondrejnice & R310W310 & 79.50 & 72.99 & -8.2 \\
\hline 47 & Odra & R90W90 & 83.70 & 74.44 & -11.1 \\
\hline 48 & Polančice & R60W60 & 82.30 & 73.35 & -10.9 \\
\hline 49 & Odra & R50W50 & 82.60 & 74.74 & -9.5 \\
\hline 50 & Porubka & R10W10 & 80.69 & 72.87 & -9.7 \\
\hline 51 & Odra & R40W40 & 83.40 & 79.38 & -4.8 \\
\hline
\end{tabular}

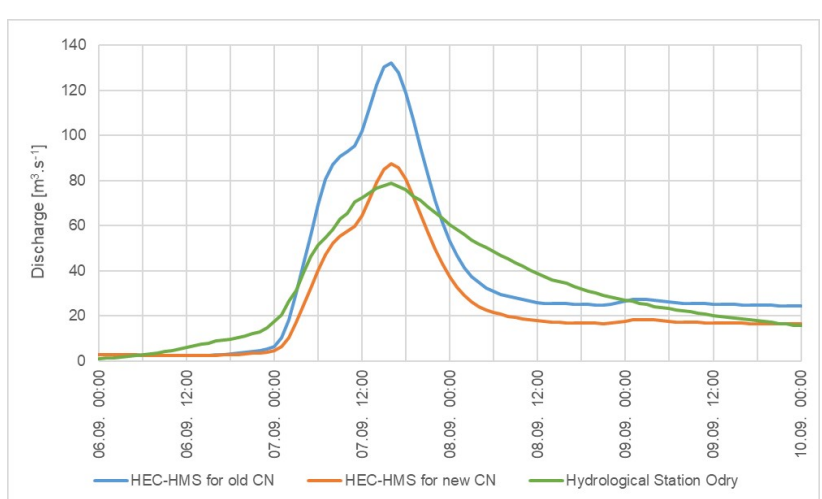

Fig. 4 Comparison of simulated and observated discharges in the Odra profile on the Odra River in September 2007

Justifiability of the assumption of the need for adjustment of runoff $\mathrm{CN}$ values as one of the important parameters determining the rainfall-runoff ratio has been verified not only for the flood episode in September 2007 but also during the last bigger discharges occurring in the study area in April 2017 and July 2018. It concerns two different hydrological situations because the episode from April 2017 was mainly caused by melting snow whereas the episode from July 2018 was caused by prolonged intensive precipitation. In the FLOREON+ system user interface, hydrological analysis of these two situations were performed including configuration of the derived parameters of runoff $\mathrm{CN}$. The simulation results have confirmed that the proposed adjustment of runoff curve numbers values provides a better approximation to the observated discharges (see Fig. 5). A similar study focused on flood wave simulations on small ungauged areas was presented by (Shakti et al. 2017). Although the assumption of the need for adjustment of runoff $\mathrm{CN}$ values parameters was justified, it is generally known that formation of surface runoff is also affected by other factors such as initial loss dimension. These parameters shall thus become the subject matter of further research with the objective to further approximate towards the measured discharge rates at hydrological stations. Within the RainfallRunoff model, the newly derived values of runoff $\mathrm{CN}$ will be integrated to the map interface of the FLOREON+ system. The results of this study shall thus be applied in practice in order to give more precision to the simulated discharge. 


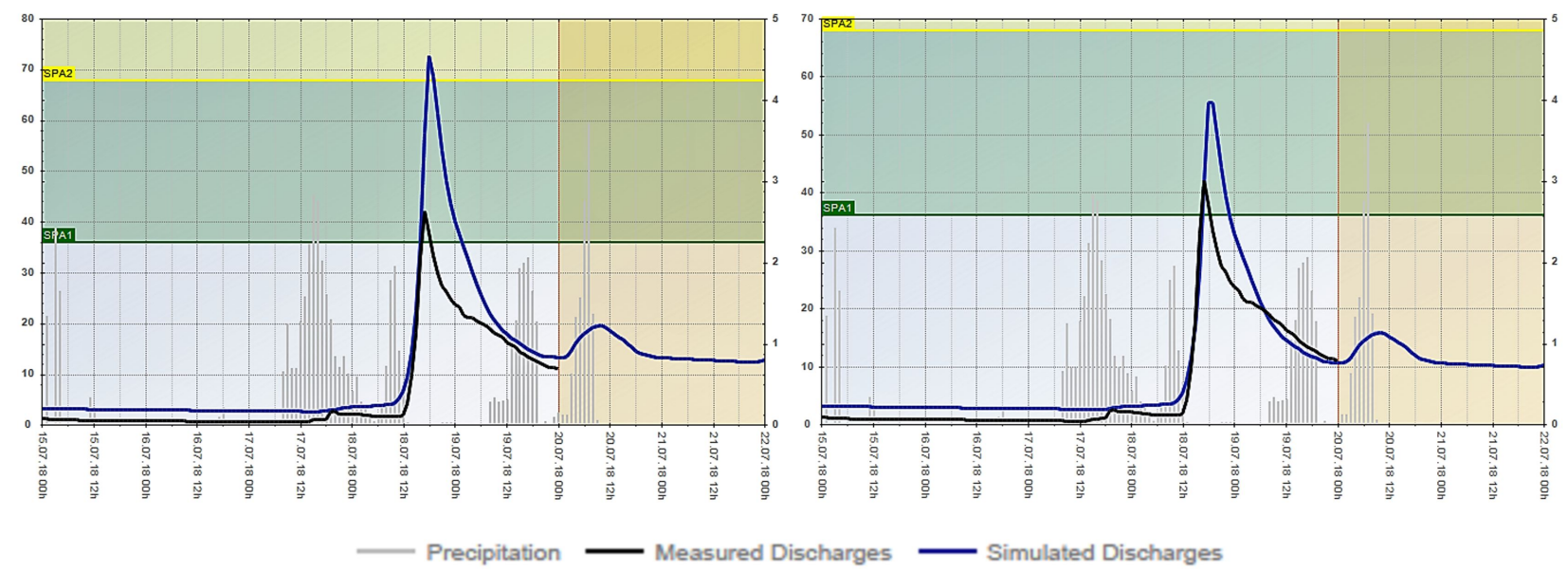

Fig. 5 Comparison of original and newly simulated discharges in the pilot Lubina River basin in July 2018

\section{Conclusion}

The curve numbers method for simulating surface runoff has been applied for several years now. The main contribution of the proposed study, however, was the derivation of the partially automated procedure using the state-of-the-art computer technology as well as up-to-date maps showing soil conditions and land cover. The above-mentioned procedure allowed us to recalculate runoff ratio up to the smallest area scale possible as a result of intersection of hydrologic soil groups with the respective land cover type. Derivation is based on the original principles determined by the US Soil Conservation Service and can be applied to any river basin in the area of the Czech Republic. Further studies will be aimed at verification of runoff $\mathrm{CN}$ for other parts belonging to the Odra River basin in the Moravian-Silesian region. It should be followed by focusing on increasing accuracy of other parameters having an effect on formation of surface runoff as well. Recalculation of runoff $\mathrm{CN}$ parameters has been tested in the case of the pilot Porubka and Lubina River basins. It has then been executed for the entire Odra River basin up to the confluence with the Opava River. The results have shown that the runoff curve numbers represent one of the most essential parameters used in RainfallRunoff models for recalculation of the rainfall volume to the discharge of water through riverbeds. The quality of their derivation can be retrospectively verified in profiles of hydrological stations where discharge is directly measured. The proposed procedure allowed us to find closer relation between simulated surface runoff and actually evaluated data. The derived method can be applied to any other river basins as well.

\section{Notes}

1 Older version of the HEC-HMS was used in order to ensure compatibility of the input datafiles resulting from calculations made during the previous research.

\section{Acknowledgement}

This work was supported by the Ministry of Education, Youth and Sports from the National Programme of Sustainability II (NPS II) within the "IT4Innovations excellence in science LQ1602" project.

\section{References}

Al-Zahrani MA (2018) Assessing the impacts of rainfall intensity and urbanization on storm runoff in an arid catchment. Arabian Journal of Geosciences 11: 208.

Apel H, Thieken AH, Merz B, Blöschl G (2006) A Probabilistic Modelling System for Assessing Flood Risks. Natural Hazards 38: $79-100$.

Bracken LJ, Croke J (2007) The concept of hydrological connectivity and its contribution to understanding runoff-dominated geomorphic systems. Hydrological Processes 21(13): 1749-1763.

CENIA. Půdní mapa ČR 1:250 000 - klasifikace dle TKSP a WRB. <http://geoportal.gov.cz/ArcGIS/services/CENIA/cenia_typy_pud/mapserver/WMSServer?>

CPD-74 A (2016) Hydrologic Modeling System HEC-HMS. User's Manual, US Army Corps of Enginners, Hydrologic Engineering Center, Davis.

European Environment Agency. CLC 2012, < https://land.discomap.eea.europa.eu/arcgis/services $>$ IT4Innovations. Floreon+ Web Client <https://floreon.vsb.cz/mapa>

Janeček, M. et al. (2012) Ochrana zemědělské půdy před erozí. Česká zemědělská univerzita, Praha.

Ministerstvo zemědělství (2019) Veřejná služba BPEJ (updated monthly, hosted on ArcGIS online). <http://services7.ar- 


\section{S sciendo}

cgis.com/xQldfwn7vL7z10wM/arcgis/rest/services/BPEJ/FeatureServer>

National Engineering Handbook (1972) Estimation of direct runoff from storm rainfall. Section 4 Hydrology, Chapter 10, Soil Conservation Service, Washington.

National Engineering Handbook (2004) Hydrologic Soil-Cover Complexes. Part 630 Hydrology, Chapter 9, United States Department of Agriculture, Washington.

Novotný I, Vopravil J, Kohoutová L ... Žížala D (2013) Metodika mapování a aktualizace bonitovaných půdně ekologických jednotek. Výzkumný ústav meliorací a ochrany půdy, Praha.

Panagos P, Imeson A, Meusburger K, Borrelli P, Poesen J, Alewell C (2016) Soil Conservation in Europe: Wish or Reality?. Land Degradation and Development 27(6): 1547-1551.

Řehánek T (2008) Povodeň v Jeseníkách v září 2007. In: Hydrologická ročenka ČR 2007. Český hydrometeorologický ústav Praha, pp. 142-146.

Šercl P (2009) Vliv fyzickogeografických faktorů na charakteristiky teoretických návrhových povodňových vln. In: Sborník prací ČHMÚ 54, Český hydrometeorologický ústav, Praha.
Shakti PC, Nakatani T, Misumi R (2017) Hydrological Simulation of Small River Basins in Northern Kyushu, Japan, During the Extreme Rainfall Event of July 5-6, 2017. Journal of Disaster Research 13(2): 396-409.

Soulis KX, Valiantzas JD (2012) SCS-CN parameter determination using rainfall-runoff data in heterogeneous watersheds the two-CN system approach. Hydrology \& Earth System Sciences 16: 1001-1015.

Svatoň V et al. (2018) Floreon+: A Web-Based Platform for Flood Prediction, Hydrologic Modelling and Dynamic Data Analysis. In: Ivan I, Horák J, Inspektor T (eds) Dynamics in GIscience. GIS OSTRAVA 2017. Lecture Notes in Geoinformation and Cartography. Springer, Cham.

Technical report No. 40 (2000) CORINE land cover technical guide - Addendum 2000. European Environment Agency, Copenhagen.

Younis SMZ, Ammar A (2018) Quantification of impact of changes in land use-land cover on hydrology in the upper Indus Basin, Pakistan. The Egyptian Journal of Remote Sensing and Space Sciences 21(3): 255-263. 